\title{
A Quest for Authority and Autonomy
}

\author{
In order to compensate for its [the Sublime Porte's] inexperience, \\ its notorious impotence, even its ill-will, the [Great Powers'] govern- \\ ments deemed it expedient to invest their plenipotentiaries with a \\ part of their sovereign rights. \\ ÉDOUARD-PHILIPPE ENGELHARDT, 1866
}

\section{On Dual Institutional Hosting}

The relationships between international organisations and their host cities and states are multifarious and complex. Since the 1870s, when Scottish law professor James Lorimer discussed the 'want of an international locality' which would belong 'to all nations and to none' in particular and which would serve as a 'centre of international life', the study of IOs' location and status has been pursued from several perspectives by legal experts, international relations scholars and economists. ${ }^{1}$ Some authors referred to the incentives of states to create 'internationalised zones' and attract IOs to their national territory, which would provide host states with economic and political advantages. Others have looked at the interests of IOs, as their agents negotiate headquarters agreements guaranteeing a large degree of independence for their secretariat and staff, together with privileges and immunities for the organisation and its employees. Not least of all, local authorities are significant actors in

1 Clarence Wilfred Jenks, The Headquarters of International Institutions - A Study of Their Location and Status (London 1945); A.S. Muller, International Organizations and Their Host States: Aspects of Their Legal Relationship (The Hague, London and Boston 1995); Niels Blokker, 'The Independence of International Organizations from Their Host States: From Theory to Practice,' online on the website of the Council of Europe (https://rm.coe .int/1680oco93e) (visited on 27 April 2018). 
the acquisition and maintenance of IOs, ${ }^{2}$ which can contribute to shaping or strengthening their cosmopolitan and liberal identity. ${ }^{3}$

By the time Lorimer published his essay the world was populated with only a handful of IOs. However, one of them had managed to secure a great level of autonomy; in fact, it was seated in two localities, one of which enjoyed the status of being an 'internationalised zone', where legal security for its headquarters, assets and staff was guaranteed by an agreement between Europe's Great Powers. This peculiar outcome was the result of a complex historical process in which an instrument of 'collective imperialism' (the European Commission of the Danube $)^{4}$ met with weak states struggling to control a vital portion of their territory - the Danube Delta. The Commission thus came to assume a larger role than that envisioned by its creators, and it gradually gained autonomy and authority in the region as a way of fulfilling its technical function.

This section will briefly discuss how the Commission came to settle its headquarters in the Danubian port-cities of Galați and Sulina, and how this decision shaped both the IO's identity and the history of its two locations. Further on, the chapter will detail, along the institutionalist analytical layer, the early history of the Commission, with a focus on its inner structure, decisionmaking mechanisms and gradual transformation into an autonomous organ. The organisation's authority increased over time with attributes acquired from below, and relevant episodes are presented on its agency in bringing stability to the Danube Delta. The making of a transnational 'community of experts' in the navigation of international waterways will also be approached. These experts established a functional security regime with rules and enforcing organs along the Maritime Danube but equally, they disseminated their knowledge beyond the region and contributed, as was the case with the supranational character of the Central Commission for the Navigation of the Rhine, ${ }^{5}$ towards further European integration. All in all, the chapter will present how, in the first decade of its existence, the Commission acquired skilled human resources, drafted a constitutional charter and got the Great Powers' approval

2 Herman van der Wusten, "Legal Capital of the World": Political Centre-Formation in The Hague,' Tijdschrift voor economische en sociale geografie 97.3 (2006): 253-266.

3 Thore Newmann and Anne Peters, 'Switzerland,' in: August Reinisch (ed.), The Privileges and Immunities of International Organizations in Domestic Courts (Oxford 2013), 241.

4 Constantin Iordachi, 'Collective Imperialism: The European Commission of the Danube, 1856-1918/1920,' paper presented at the Fifth European Congress on World and Global History, Budapest, 31 August-3 September 2017 .

5 Guido Thiemeyer and Isabel Tölle, 'Supranationalität im 19. Jahrhundert? Die Beispiele der Zentralkommission für die Rheinschifffahrt und des Octroivertrages 1804-1851,' Journal of European Integration History 17.2 (2011): 177-196. 
to extend its mission from regulating navigation along the Maritime Danube to that of acting as a pillar of order and security in an area still unsettled after the territorial and demographic shifts brought by the Crimean War.

The first point of discussion is the headquarters issue. The choice of an initial meeting place for the seven European envoys was a rather simple decision for the governments who participated in the 1856 Paris Congress. They ordered their delegates to convene in the commercial capital of the Lower Danube, the Moldavian port-city of Galați, which stood about 100 miles inland from the Black Sea coast. The place lay about 30 miles outside the jurisdiction of the Commission, though the logic behind its works was to allow seagoing ships easier and safer access to the ports of Galați and Brăila, the outlets of the Principalities of Moldavia and Wallachia. This situation of commissioners sitting in Moldavia to regulate navigation on a river section in the Ottoman Empire would bring complications and attempts to either move the Commission to its territorial jurisdiction or to extend the latter all the way to (at least) Galați. The extension was eventually decided through the 1878 Berlin Treaty (Chapter 8).

Galați was relatively well connected to Tulcea (the administrative capital of the Ottoman province that included the Danube Delta) and Sulina by steam packets plying regularly to Istanbul. A city of about 30,000 inhabitants in 1856 , Galați had rapidly grown due to its prosperous grain trade. It had the appearance of a 'topsy-turvy' and busy Oriental city, but consuls, local officials and well-off merchants had built 'European' houses in new districts that displayed, according to some accounts, 'taste and elegance'. For Patrick O'Brien, the Irish traveller who visited it in 1853, Galați was a prosperous city, with good and tolerably well-paved roads; 'in the principal streets are some handsome shops', he added, 'and there is everywhere a pleasing appearance of bustle and prosperity'.6 Karl Hermann Bitter (1813-1885), the first Prussian commissioner to the Commission, noticed 'its grey roofs, white houses, churches with their towers sparkling in the sun, the whirling dust-clouds, the forest of masts along its harbour', and its many rascals and criminals of all nations. ${ }^{7}$ From all perspectives, Galați was a busy Levantine commercial hub, where East met West.

Galați was chosen to host the sittings of the Commission as, in the words of John Stokes, the first British commissioner, it was the nearest town to the

6 Patrick O'Brien, Journal of a Residence in the Danubian Principalities in the Autumn and Winter of 1853 (London 1854), 23-24.

7 Karl Hermann Bitter, Skizzen und Bilder aus den Ländern an den unteren Donau und aus dem europäischen Orient aus den Jahren 1856 bis 1858, in: Heinz-Peter Mielke, Karl Hermann Bitter. Stationen eines Staatsmannes (Minden 1981), 40, 48. 
Danube Delta 'with any pretensions to western civilization.8 8 It was a convenient seat for diplomatic negotiations between the seven delegates, who could find relatively decent accommodation and living conditions for them and their families. Galați was also well served by regular steamers, allowing delegates and their staff to easily proceed to the Danube Delta, but also to reach major European communication hubs, such as Istanbul or Vienna. A telegraph line connected it to the capitals of the two Principalities and to the world at large, permitting delegates to be in touch with their countries' foreign offices. Galați also seemed like an appropriate choice given the uncertainty as to which branch of the Danube was to be improved. Until a choice was made between Chilia, ${ }^{9}$ Sulina and St George, commissioners and the Commission's increasing bureaucratic staff could enjoy the better life of a, by local standards, modern city.

The town of Sulina was home to the Commission's Technical Department. As Sulina was, in 1856 , the only navigable branch of the Danube, the small town at the junction of river and sea housed the engineering staff studying the area and the bureaucrats involved in enforcing the IO's early regulations. The Sulina mouth was eventually chosen for provisional and permanent improvement, and it remained the home base for the Commission's hydraulic and navigational operations.

The 186os was a period of extreme uncertainty for the Commission, whose prolongation depended upon a unanimous agreement of its seven member states. Its term was extended by five years in 1866, and by twelve more years in 1871. By then, its inner regulations had changed a lot, and the Commission's daily business was run by an Executive Committee comprised of two commissioners. It was in this context that further debates emerged in relation to the Commission's seat.

In April 1871, a proposal was made to build a modern headquarters at Galați, as the Commission's services were housed in improper conditions for the size and social status of its staff. ${ }^{10}$ Discussions continued in July 1871 , when Baron Adolphe d'Avril, the French commissioner, inquired into the possibility of moving the IO's seat to Ottoman territory, to Tulcea or Sulina. Stokes, the long-standing British delegate, replied by mentioning the three advantages of keeping the Commission at Galați: it provided better communication with the

8 John Stokes, Autobiography (s.l. s.a.), 63 .

9 The Romanian form 'Chilia' will be used throughout this volume. In nineteenth-century English and French sources 'Kilia' was used, whereas in Ukrainian the name is now transliterated as 'Kiliya.'

10 National Archives of Romania, Galați Branch, Protocols of the European Commission of the Danube (hereafter PECD), Protocol 253, 24 April 1871. 
commissioners who held other diplomatic functions, it allowed them to regularly meet, and the organisation worked amidst the mercantile community that benefited most directly from its technical works. Ismail Bey, the Ottoman delegate, pledged his government's support in improving communications with Sulina and his personal involvement with the Executive Committee in case of a change," but most delegates considered that Galați better served the needs of the Commission's diplomatic and administrative branches. ${ }^{12}$ Ismail Bey resumed the debate in April 1872, insisting that by moving the seat to Sulina, the Commission would significantly reduce its expenses, allowing commissioners closer supervision of the institution's navigational and technical departments. Several commissioners supported him, ${ }^{13}$ but their governments' political decision was to stick to Galați as the Commission's Central Office (with the Secretariat) and to have Sulina as the operational base for most of the executive services. ${ }^{14}$

Given the complicated political relations between the Ottoman Porte and its vassal state, there was no formal agreement with Moldavia (and later with Romania) to host the organisation. The central and local authorities in Moldavia were informed about the Commission's initial meeting in 1856 and were urged to give it any necessary support. This, however, did not transpire and the commissioners kept complaining about the Moldavian authorities' lack of deference for their activity. The organisation may not have received due consideration during its early days, but the commissioners did start to blend socially with the cosmopolitan elite of the busy commercial port-city.

Things gradually changed, and with Romania joining the quasi-permanent IO in 1878 the Romanian commissioners further positioned the Commission into a central role within local communal life. By the late nineteenth and early twentieth centuries, as the Commission continued to invest in shaping its image, the Commission's 'administrative palace' in Galați (completed in the mid-189os-see Fig. 12) became a fashionable hot spot for local elites, which included 'the consuls, the heads of big shipping houses, bankers of different nationalities, landed proprietors and army officers'.15

For Ethel Greening Pantazzi, the young Canadian wife of a Romanian naval officer,

\footnotetext{
11 Ibid., Protocol 256, 4 July 1871.

12 Ibid., Protocol 262, 2 November 1871.

13 Ibid., Protocol 268, 30 April 1872.

14 Ibid., Protocol 276, 11 November 1872.

15 Ethel Greening Pantazzi, Roumania in Light \& Shadow (Toronto 1921), 79.
} 
Galatz has a charm of its own; it is quite different from any other Roumanian town, chiefly because it is the residence of the European Commission of the Danube. The eight Commissioners represent Britain, France, Italy, Austria, Germany, Turkey, Russia and Roumania, and, with the exception of the French delegate, have residences in Galatz and remain the year round. They are the natural leaders of their colonies, and do a good deal of entertaining, which has the charm of the unexpected, for one meets people from the four corners of the earth. Besides receiving in their own homes, they give, collectively, balls and other fetes every spring and autumn in the palace of the Commission, a large building where their meetings are held. ${ }^{16}$

If at Galați the Commission's headquarters had become a trendy meeting place for the elites of a busy commercial hub (whose population numbered about 70,000 inhabitants in the early 190os), the Commission was even more central to communal life in Sulina. With hundreds of Commission employees amongst the 7,000 or so local inhabitants, and with the rest making their living from commercial and shipping ventures in the local harbour, the IO was 'the supreme source of Sulina's prosperity'. ${ }^{17}$ This centrality is visible in the Commission's involvement in almost every aspect of communal life, from Sulina's urban planning to its role in the educational or religious development of the town (see Chapter 9).

A marked difference existed between the two seats throughout the Commission's long history. Galați was the diplomatic and administrative centre, a corporate head office that dealt with managerial aspects such as strategic planning, decision-making, governance, communication, human resources and funding. Sulina was the Commission's main working place, serving as the operational centre wherefrom navigational safety was coordinated. A hierarchical relation developed between the two, with Sulina as the peripheral and 'colonial' branch in which, however, the Commission's privileged status was fully recognised. The Commission represents a special case in which an IO settled its provisional headquarters in two separate political entities and set a firmer spatial hold as its term got extended and it eventually became a quasipermanent institution. Bridged between its diplomatic corporate offices in Galați and its operational base in Sulina, the Commission managed to balance its increasingly complex functions as the protector of the Maritime Danube's shipping security.

$\begin{array}{ll}16 & \text { Ibid., } 77-78 . \\ 17 & \text { Ibid., } 125 .\end{array}$


The maiden commissioners appointed to the Commission played a crucial role in its institutional survival and development. Delegates shaped the organisation to suit their states' interests, but also their own expertise and personality traits. At the same time, the shared experience of crafting an organisation from scratch and dealing with the many dimensions involved in this process broadened the commissioners' competencies. Some of them would gradually become part of a larger 'community of experts' in transboundary rivers, and their knowledge spread around the world. The stories of the seven maiden delegates are perhaps illustrative of the quality of the human resources involved in the early regulation of the Maritime Danube and of how they benefited from new skills after their Danubian careers.

Prussia's Bitter found it difficult to adapt to living in Galați. He had studied law and public administration, and for almost two decades had worked as public servant in different Prussian provincial administrations. He was familiar with regulating inland navigation and in the early 1850 os was involved with the commission for the navigation of the Weser. But his too liberal convictions made him undesirable to his superiors, and his appointment to the Commission was more like a disciplinary measure than a promotion. Galați was not the place where Bitter could indulge his passion for Bach, Mozart, Handel or Wagner, on whose music he later published several books. But he had the liberty to paint, leaving numerous sketches of Danubian daily life (see Figs. $5^{-6}$ below). Bitter was an experienced official, and his bureaucratic 'pencil' is visible in the Commission's drive towards law and order. Bitter's expertise in international rivers secured his transfer in 1860 to the Rhine Commission (which he tried to reform on the Danube Commission's model) and his access to higher political offices. By the 1870 s he held top governmental and administrative positions in Prussia and the German Empire, including that of Finance Minister in one of Bismarck's cabinets. ${ }^{18}$

His Austrian colleague, Franz Karl von Becke (1818-1870), would later serve as Finance Minister of the Double Monarchy. He was a law graduate who had joined the Viennese Foreign Office as a career diplomat. By the late $1840 \mathrm{~s}$ Becke had been appointed to various positions at the consulates of Galați and Alexandria, and before the Crimean War worked for the Austrian Ministry of Commerce. His nomination to the Commission was as a result of his juridical and diplomatic expertise, but also his knowledge of the Lower Danube. After six years spent in Galați, he was appointed Vice-President of the Austrian 
Maritime Authority in Trieste in 1862 and later crawled his way up to the capital's political elite. ${ }^{19}$

Édouard-Philippe Engelhardt (1828-1916) was a young diplomat when he joined the Commission in November 1856. He had studied law in Strasbourg, and soon after graduation joined the French consular service. Until 1856 he held several minor positions at the French consulates in Mainz and London. At the former he became familiar with the activity of the Central Commission for the Navigation of the Rhine, and such expertise might have influenced the French Foreign Office's decision to appoint him to the position at the Maritime Danube. ${ }^{20}$ He was in London in June 1856 when he received his nomination ${ }^{21}$ to the Commission. As will be detailed below, Engelhardt remained in Galați for eleven years, and his expertise made him one of the leading European authorities in international fluvial law.

John Stokes (1822-1902) was another key protagonist in the Commission's gradual metamorphosis into an autonomous IO. He had studied at the Royal Military Academy in Woolwich and the Military Engineering School in Chatham, and served in South Africa in the 1840 s. He was an instructor in surveying and field works in Woolwich and, as a military engineer, was entrusted in 1854-1855 with forming an Engineer Corps that was to assist an Ottoman contingent in the anti-Russian campaign. His energy and administrative efficiency brought him the appointment to the Commission, a decision that changed his whole life. Stokes became one of Britain's most influential experts in the regulation of international waterways and was later appointed vicepresident of the Suez Canal Company Board (more on him in Chapter 6). ${ }^{22}$

The other three commissioners were military and naval officers invested by their governments with administrative and diplomatic duties. Ömer Fevzi Pasha (1818-1878) had served in the Ottoman army during the Crimean War and became governor of the Ottoman sandjak of Tulcea. After his province incorporated the Danube Delta in $185^{-1857}$, Ömer Pasha commuted to Galați from his headquarters at Tulcea to attend the Commission's meetings.

19 Wolfgang Fritz, Für Kaiser und Republik: Österreichs Finanzminister seit 1848 (Vienna 2003), 50-51.

20 Centre des Archives diplomatiques de La Courneuve (CADC), Personnel dossiers individuels, Éd. Engelhardt; Albert Ronsin, Les Vosgiens célèbres: dictionnaire biographique illustré (Louis 1990), 128.

21 Centre des Archives diplomatiques de Nantes (CADN), Représentant de la France auprès de la Commission Européenne du Danube, Série B, File 7, f. 2 (Count Walewski to Engelhardt, Paris, 3 June 1856).

22 The Dictionary of National Biography: 1901-1911, edited by Sidney Lee (Oxford 1912), 424426; Who Was Who, vol. 1, 1897-1916 (London 1920), 68. 

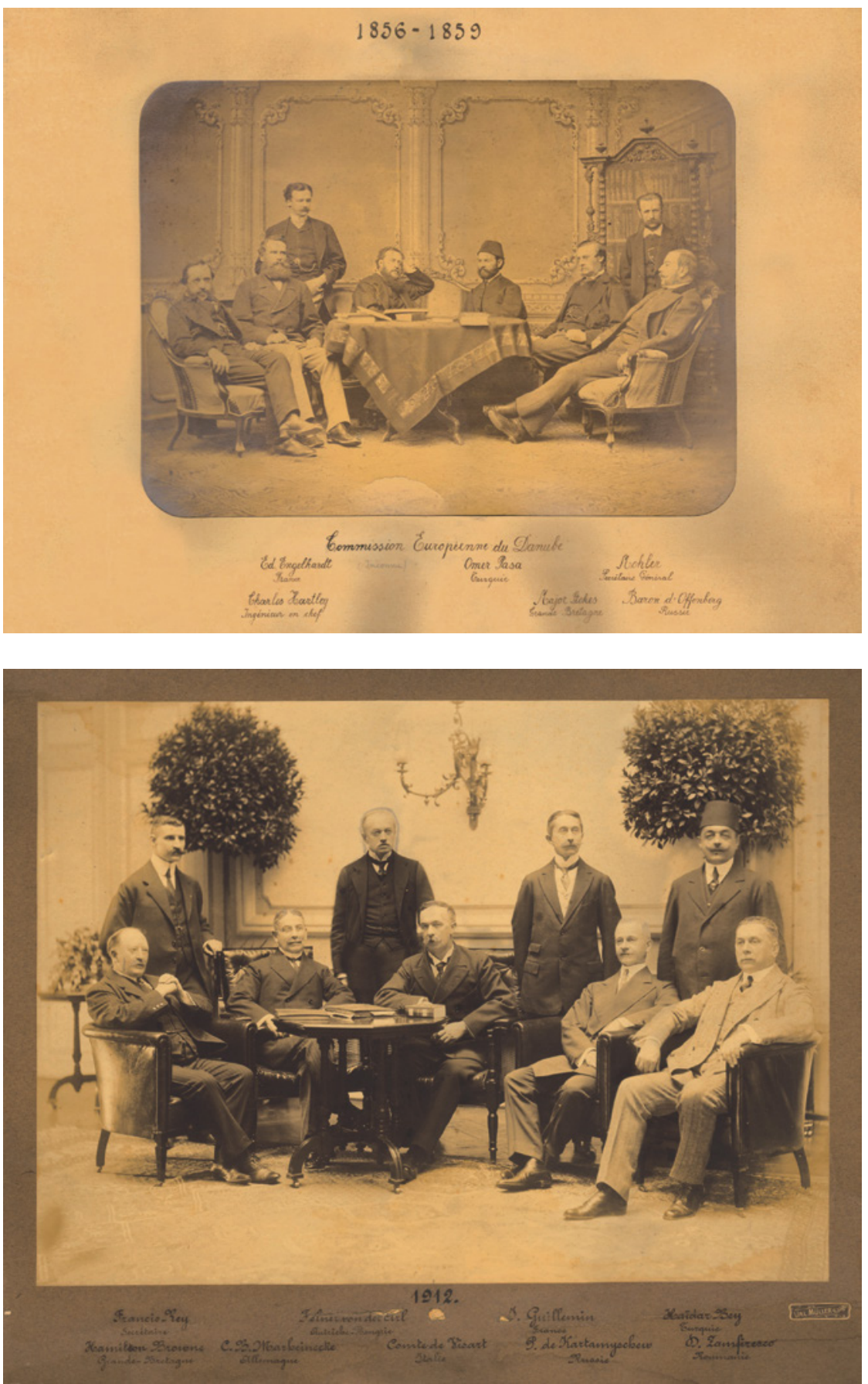

FIGURES 2-3 Group photos of the Danubian commissioners (ca. 1857-1859 and 1912) SOURCE: NATIONAL ARCHIVES OF ROMANIA, GALAT,I BRANCH 
Henrik d'Offenberg, Baron of Courland (1821-1888) was equally familiar with the Lower Danubian area, but as a diplomat he had to fulfil other responsibilities at the Russian consulate in Bucharest. ${ }^{23}$ Alessandro d'Aste Ricci (1814-1881) was an experienced seafarer in the Sardinian navy and had held the position of director of the Naval School in Genoa. His appointment to the Commission was linked most probably to his skills in seamanship. ${ }^{24}$

These brief biographical notes indicate some of the reasons governments had for appointing their maiden delegates to the Commission. They all had some knowledge related to one of the multiple dimensions of shipping (juridical, hydraulic, administrative or naval). They were involved in the regulation of other European rivers (the Weser and the Rhine) or had diplomatic experience in the Levant. The expertise commissioners acquired in Galați proved highly valuable to their cabinets' growing interest in the regulation of international rivers and canals in Europe, and around the world. Many of these early delegates became authorities in international waterways and formed a 'community of experts' 25 that further disseminated their knowledge to the Rhine, the Suez Canal or to other waterways and ports. They were often involved in the selection or training of their successors, whose diplomatic skills needed to be accompanied by proper knowledge of the regulation of conventional rivers. They became role models in the organisation and contributed to the gradual formation of an institutional culture. ${ }^{26}$ Not least of all, they equally used their proficiency to be promoted to more influential diplomatic or governmental positions, in which they continued to support European cooperation.

Several theories on decision-making in IOs have tried to account for the ways in which such organs function as corporate entities. Regarded as black boxes' that convert the states' inputs (demands or interests) into outputs

23 Lee B. Crost, Asgleigh Albrecht, Emily Cluff and Erica Resmer, The Ambassadors: U.S. to Russia/Russia to U.S. (Phoenix 2010), 119-120.

24 Details available at 'Alessandro d'Aste. Tenente di vascello, Medaglia d'oro al Valor Militare', online at http://www.marina.difesa.it/noi-siamo-la-marina/storia/la-nostra -storia/medaglie/Pagine/Dastealessandro.aspx (visited on 20 January 2019).

25 More on this in Luminița Gătejel, 'Imperial Cooperation at the Margins of Europe: the European Commission of the Danube, 1856-65, European Review of History/Revue européenne d'histoire 24.5 (2017): 781-80o.

26 Marc Abélès and Henri-Pierre Jeudy (eds.), Anthropologie du politique (Paris 1997), 154-155. 
(international agreements), IOs are structures whose behaviour is worth following in terms of processes such as agenda setting, deliberations on pending issues, voting procedures and outcomes etc. ${ }^{27}$ This empirical study is illustrative of the history of decision-making mechanisms in nineteenth-century IOs, and it is equally relevant for understanding how the Commission managed to survive for such a long time. The entire organisational structure depended on the concurrence of several treaty provisions, on diplomatic best practices, and on a lot of common sense in assuming the best solutions for the difficult conditions of navigation along the Maritime Danube.

The seven commissioners convened in Galați on 4 November 1856 and immediately decided to draft an internal regulation to set the order of the Commission's works. ${ }^{28}$ Prussia's Bitter with his bureaucratic experience compiled it, and the regulation was discussed and approved in late November 1856 . The Commission functioned as a diplomatic assembly in which decisions were made by a majority of votes. Unanimity, however, was needed in all questions of principle. As delegate of the territorial power, Ömer Fevzi Pasha was elected president and Bitter became his assistant. With Ömer Pasha often away in his other administrative obligations (as he was governor of the Danube Delta area), Bitter played a leading role in the coordination of the Commission's daily business.

For expediency, the commissioners divided their work into several collegial committees, operating as ministries with shared administration. The technical committee consisted of d'Aste, Offenberg and Stokes, and it was charged with the coordination of the Commission's hydraulic programme, from planning the works to providing for the human and material resources necessary for completing them. The administrative committee, with Becke, Bitter and Engelhardt, had to decide on the normative component of rulemaking and prepare a set of coherent navigation regulations. The tariff committee (d'Aste, Becke and Stokes) was to study shipping practices at the Lower Danube and on other European rivers, and propose a reasonable tariff that was to provide the financial means needed for the administration of Danube navigation. Bitter was acting 'finance minister', responsible for the Commission's treasury. Each

27 Bob Reinalda, 'Decision Making within International Organizations. An Overview of Approaches and Case Studies,' paper delivered at a European Consortium for Political Research (ECPR) Workshop, 2001, 13-15 (online at https://ecpr.eu/Filestore/Paper Proposal/6161c44f-f398-45ef-a48f-o2da2d6f6cc9.pdf) (visited on 7 April 2018). See also Bob Reinalda and Bertjan Verbeek, 'The Issue of Decision Making within International Organizations,' in: eidem (eds.), Decision Making within International Organizations (London and New York 2006), 16-18.

28 PECD, Protocols 1, 4 and 5, 4, 28 and 29 November 1856. 
committee regulated in its field of responsibility, but decisions were taken in plenum by a majority of the seven delegates. ${ }^{29}$ It was this majority voting that would turn the Commission into a functional and efficient organ, capable of making sensitive decisions that were eventually accepted by all its member states.

At the same time, after preliminary research of the source material, financial and human resources available at Galați and a tour in the Danube Delta, the seven delegates became fully aware that a complex hydraulic and normative mission lay ahead of them. They decided to organise several services that were to support the Commission in the complex task of regulating river navigation. It should be reminded that innumerable obstacles impeded proper navigation along the Maritime Danube. The Danube Delta had no clear status, being occupied by Austrian troops, while its sovereignty was disputed between vassal Moldavia and the Ottoman Porte. Sulina was the only navigable river branch, but it was in a deplorable condition. The depth over the bar was insufficient, and commercial traffic continued by means of lighters owned by transnational 'pirates'. Despite Austrian attempts to impose control, anarchy and disorder ruled at Sulina, which remained the haven of numerous adventurers in search of easy profits (see Chapter 9). ${ }^{30}$ Commissioners understood that they needed more than their diplomatic talents to solve these problems, and planted the roots of a complex bureaucratic structure when they founded a Secretariat to take care of the Commission's official correspondence and a Technical Department for the coordination of its hydraulic works.

The initial collegial system stayed in use for two busy years, during which the seven delegates worked tirelessly to regulate Danube navigation. A total of 89 protocols were concluded in 24 months, with commissioners meeting at Galați on a daily basis. However, in August 1858 the ambassadorial conference of Paris prolonged the organisation's term until the completion of its Sulina works, and as several delegates received from their governments other diplomatic/ administrative duties, a more flexible 'charter' was voted in November 1858 . The Commission was to convene in plenum once a week and daily activities were directed by an Executive Committee. It was made up of two commissioners, one responsible for the organisation's Secretariat (Administration Delegate), the other for its Cash Office (Finance Delegate). Apart from the Ottoman president, whose functions were protocolary, the other six delegates rotated monthly in these offices, in alphabetical order of their countries' names. ${ }^{31}$

29 La Commission Européenne du Danube et son œuvre de 1856 à 1931 (Paris 1931), 66-67.

$30 \quad$ Ibid., 563.

$31 \quad$ PECD, appendix to Protocol 89, 4 November 1858. 
The commissioners' involvement in the institution was unequal. It depended on three main factors: their states' interest in securing international control over the Maritime Danube, their own vision of the Commission's role and future, and the other diplomatic duties they received from their governments. Due to their countries' political and economic interests, Stokes, Engelhardt and Becke were the most active commissioners, together with Prussia's Bitter, whose imposing character made him assume leadership. Offenberg fulfilled his duties fairly, though Russia formally refused to play any key role in an organisation that resulted from its defeat in the Crimean War and regulated navigation in former Russian imperial waters. In March 1859, d'Aste returned to the Italian peninsula and a new Sardinian (Italian) delegate was appointed only in August 1860: Annibale Strambio, his country's Agent and General Consul to Bucharest, was to commute from Wallachia's capital to Galați to attend the Commission's meetings. Bitter left in October 1860 and was replaced by Jules Alexander Aloyse de Saint-Pierre, Prussia's Agent and General Consul to Bucharest, who attended the Commission's meetings from May 1861. As Offenberg was also based in Wallachia's capital, the three delegates who resided at Galați (called 'resident commissioners') - Becke, Engelhardt and Stokes dominated the Executive Committee during the early 1860 .

Becke was his country's consul to Galați, and Austria launched the model of employing consuls in Moldavia's port-city to also serve as commissioners. Stokes was appointed Britain's General Consul for the Danube Delta, and Engelhardt requested a similar position along the Middle and Lower Danube, as consular powers granted commissioners more authority in relation to their fellow countrymen. A reorganisation of the position of France's Danubian commissionership occurred in 1867, when Engelhardt was appointed French Consul to Belgrade, and Baron Adolphe d'Avril, French General Consul to Bucharest, took over his responsibilities in the Commission. By the early $1880 \mathrm{~s}$ Britain also merged the position of Danubian commissioner with that of consul to Galați.

A new step towards the flexibilisation of the Commission was taken in 1864, when the seven delegates decided to have two plenary sessions per year, in spring and autumn. Other changes followed, with the view of allowing non-resident delegates a more active involvement in the organisation's transactions. ${ }^{32}$ All major decisions were to be taken during plenary sessions, while the Executive Committee and chiefs of services ran the organisation's daily business. A further professionalisation of delegates is visible once the Commission turned into a quasi-permanent institution and local consuls were 


\section{Austria (Austria-Hungary)}

Franz Karl von Becke (1856-1862)

Alfred von Kremer (1862-1869)

Nicholas Zulauf von Pottenburg (1869-1871)

Ottocar Freihher Schlechta Wehrhrd

(1871-1872)

Gustav Ritter v. Gröller (1874-1875)

Ernst von Haan (1875-1882)

Karl von Boleslawski (1882-1889)

Karl Ritter von Gsiller (1890-1895)

Moritz Freiherr Czikann-Wahlborn (1896)

Hugo II Logothetti (1897-1898)

Viktorin von Borhek (1899-1911)

Alfons Felner von der Arl (1912-1916)

\section{France}

Édouard-Philippe Engelhardt (1856-1867)

Adolphe d'Avril (1867-1876)

Jules Herbette (1877-1879)

Camille Barrère (1880-1883)

André Lavertujon (1883-1885)

Frederic Guéau, Marquis de Reverseaux de

Rouvray (1885-189o)

Comte L. d'Aubigny (1891)

Georges Cogordan (1891-1894)

Joseph Adam Sienkiewicz (1894-1895)

Constantin Jules Paillard-Ducléré

(1896-1902)

Marcellin Pellet (1902-1906)

Pierre de Margerie (1906-1907)

Gabriel Pierre Deville (1907-1908)

André Soulange-Bodin (1909-1911)

Jean Marie August Guillemin (1911-1916)

\section{Great Britain}

John Stokes (1856-1871)

Charles Gordon (1872-1873)

Herbert Taylor Siborne (1874-1881)

Percy Sanderson (1882-1894)

Henry Trotter (1894-1906)

Hamilton Browne (1907-1912)

John Baldwin (1913-1916)

\section{Ottoman Empire}

Ömer Fevzi Pasha (1856-1863)

Rashid Pasha (1863)

Mehmed Sabri Pasha (1864)

Ahmed Rassim Pasha (1864-1867)

Suleyman Pasha (1867-1869)

Ismail Kemal Bey Vlora (1870-1872)

Fahri Bey (1873-1875)

Madjid Bey (1876)

Aali Bey (1876)

Mehmed Said Pasha (1877)

Constantin Effendi Et. Caratheodory

(1878-1885)

Artin Effendi (1886-1887)

Maxime Effendi Varhaliti (1888-1889)

Manuk Azarian Effendi (189o-1908)

Ihsan Hüsnü Effendi (1908-1911)

Hassan Haydar Bey (1911-1916) 
TABLE 1 List of European commissioners, 1856-1916 (cont.)

Prussia (Germany)

Karl Hermann Bitter (1856-186o)

Jules Alexandre Aloyse de Saint-Pierre (186o-1867)

Heinrich Keyserling Rautenburg (1868-1869)

Joseph Maria von Radowitz (1870-1872)

von Pfuel (1873-1875)

Friedrich Johann von Alvensleben (1876-1877)

Johannes Arendt (1878-1885)

Franz von Aichberger (1886-1888)

Raffauf (1891-1894)

De Loehr (1895-1902)

Marheinecke (1902-1916)

\section{Romania}

G. Râșcanu (1878)

Eustație Pencovici (1879-1885)

Grigore I. Ghica (1886-1888)

A. Teriaki (1888)

Eustație Pencovici (1889)

Ion Bălăceanu (1889-1892)

Eustație Pencovici (1893-1903)

Trandafir G. Djuvara (1904)

Gheorghe G. Bengescu (1905-1906)

Constantin C. Nanu (19o6-1909)

Duiliu Zamfirescu (1909-1916)

\section{Russia}

Henrik d'Offenberg (1856-1871)

Ivan Zinoviev (1872-1875)

Dimitri Stuart (1876-1877)

Alexander Romanenko (1878-1892)

Nicolai de Lodygensky (1892-1901)

Anatol Lobanow Rostowski (1902-1903)

Piotr Kartamishev (1904-1916)

\section{Sardinia (Italy)}

Alessandro d'Aste Ricci (1856-1859)

Annibale Strambio (186o-1865)

Francesco Teccio de Bayo (1866)

Romano Susinno (1867-1868)

Berrio (1868-1872)

Cesare Durando (1873-1876)

Charles Albert Seysel d'Aix de

Sommariva (1877)

Melchiorre Simondetti (1878-188o)

Nicola Revest (1881-1886)

Giovanni Paolo De Riva (1887-1888)

G. Pascali Corte (1888-1889)

Giulio Tesi (1890-1899)

Saint Martin (1899)

Nicolas Domenico Pappalepore

(1900-1905)

Lodovico Centurione (1906)

Enrico Acton (1907-1908)

Monzani (1908)

Giuliano de Visart (1909-1914)

Alessandro Leoni $\left(1915^{-1916)}\right.$ 
appointed to represent their countries' interests in Danubian navigation. By the late nineteenth century, most commissioners (see Table 1) also served as consuls to Galați, so they devoted a large part of their time and energy to issues related to Danubian navigation and trade.

Agradual bureaucratisation of procedures was enforced, as the Commission's Secretariat matured into a fully reliable service (see Chapter 7). It coordinated with the rotating presidency, the Executive Committee and all commissioners on agenda setting, and organised deliberations on pending issues to maximise the organisation's efficiency during its plenary sessions. The majority vote rule allowed daily business to be conducted robustly, and in all issues of principle requiring unanimity, bargaining resulted in reasonable compromises. All in all, decision-making procedures imposed in the early phase of the Commission's existence survived into the twentieth century, while its most significant decisions were examined and approved by national governments, oftentimes in multilateral conferences. Such was the case with the 1865 Public Act (see below), which was sanctioned by an ambassadorial conference in Paris in 1866, further proof that the Commission acted as an institutional embodiment of Europe's Concert of Powers.

\section{Diverging Views on the Binding Force of the Commission's} Regulations

One of the Commission's first challenges was to impose its decisions throughout its territorial jurisdiction. Commissioners were quick in adopting tens of regulations, but the IO's authority to do so was questioned by several foreign merchants, ship captains and consuls based in the Danube Delta area.

The latter justified their position in several ways. Firstly, they contested the Commission's role in drafting administrative regulations, as the organisation was formally a technical institution tasked to remove the physical obstacles that hindered river navigation. Secondly, foreign subjects enjoyed, according to the capitulatory regime, a privileged status in the Ottoman dominions. Vincent Lloyd, the British vice-consul to Sulina, led the resistance against the Commission, and Stokes struggled to make the local British community accept the IO's regulations and authority. Stokes petitioned the Foreign Office several times and tried to find a diplomatic solution, which in fact meant that the Danube Delta was removed outside the Ottoman territories where the Capitulations were valid. In other words, the international order instituted by the Commission overruled the privileged position that individual states enjoyed in the Ottoman Empire. 
It took Stokes a long time to convince the Foreign Office to issue a formal statement of support for the Commission. Following a royal decision dated 6 January 1862 it was ordered that 'all rules, orders, and regulations' made and to be made by the Commission should 'be binding and in force', and should have 'the force and effect of law, upon and against all British subjects' within the dominions of the Sublime Ottoman Porte. ${ }^{33}$ By a further order of 21 March 1862, the same was extended to the rules, orders and regulations

concerning the navigation of the River Danube, or concerning the conduct and government of masters, seamen, or others navigating the same, or concerning the imposition, levying, or payment of tolls or duties to be taken or levied in respect of the navigation of the said river, or concerning the imposition and enforcing of penalties for the breach of such rules, orders, and regulations, respectively. ${ }^{34}$

The orders were amended in November 1864 and in April 1866, when British consular representatives in Ottoman territories were empowered to enforce the 1865 Public Act, as amended by the 1866 Paris Conference. ${ }^{35}$ As a result, the British government granted the Commission, as other governments had also done, the right to act in its name, an important contribution to the making of functional IOs.

Although politically disposed to grant such large attributions to a supranational entity, the British government was faced with a drawback when the issue got to a court of law. The vessel Mars of the Austrian DDSG and the Smyrna, a steamer of the British 'Greek and Oriental Steam Navigation Company', came into violent collision on 6 November 1860 close to the right bank of the Danube, about 12 miles upstream of Sulina. 'The result was very disastrous. The Mars was nearly cut in two by the stern of the Smyrna, and she almost immediately sank'. In January 1861, the DDSG sued the British company, blaming the Smyrna for the loss. The main argument was that the Commission's June 1860 regulation, in use when the accident occurred, stated that when two vessels met 'whilst proceeding in different directions, the one ascending stream must steer towards the left bank, and the vessel descending towards the right bank'. The lawyers from the Austrian company contended that the Commission's

33 Originally published in The London Gazette, No. 22587, 7 January 1862.

34 Ibid., No. 22611, 25 March 1862.

35 Hertslet's Commercial Treaties: A Complete Collection of the Treaties and Conventions, and Reciprocal Regulations, at Present Subsisting Between Great Britain and Foreign Powers, vol. 12 (London 1871), 871-873, 920-924. 
regulations were binding, and the Smyrna, ascending the river, 'ought therefore to have kept on the left or Russian [i.e. northern - C.A.] side of the river.' ${ }^{36}$

The case was judged, according to the Capitulations, by the Consular Court of Galați, which admitted, in September 1861, the two parties' petitions and declared that 'the issue to be tried was, whether the collision was caused by the fault or neglect of the Smyrna. The Court decided in favour of the British defendants, as it refused to attribute any binding force to the Commission's regulations, and 'gave its judgment on the merits of the case as if no such regulations had ever been made'. On appeal, the Supreme Consular Court of Istanbul confirmed the decision on the same grounds, adding the additional point that even if the regulations were valid, they had not been duly published. It was proved that at the time of the collision the master and pilot of the Smyrna were not aware of the Commission's regulations, which were not generally known to local pilots. ${ }^{37}$

The DDSG further appealed to a British court of law, and the appeal was judged in June 1864. The main dispute related to the question of whether the Commission had any authority to make these regulations, and all preliminary courts had agreed that it had not. The ${ }_{185} 6$ Paris Treaty did not specifically confer such an attribution to the Commission, but only invested it with technical functions. The British court of law decided that the organisation 'had no authority to issue such a code, and the regulations are therefore void'. The judges equally rejected the opinion that even if the Commission had no power to draft such documents, they 'would have validity as emanating from the sovereign of the state [i.e. the Porte - C.A.] traversed by the river'. Thus, the case was

decided on the laws and practice of navigation on the Danube as they existed before the publication of these regulations, and it is unnecessary for us to consider whether there had or had not been such a publication of them as was required in order to give them validity if there had been authority in the European Commission to make them. ${ }^{38}$

Looking to the case independently of the Commission's regulations and recollecting that the question was whether the collision occurred through the fault or negligence of the Smyrna, the decision went in favour of the British master and his pilot, who had proceeded according to prudence and wisdom.

36 Reports of the Cases Relating to Maritime Law: Decided by the Court of Admiralty, and by All the Superior Courts of Law and Equity; Salvage Awards, vol. 2 (London 1868), 94.

37 Ibid.

38 Ibid., 94-95. 
In conclusion, from a juridical perspective, the Commission had no power to issue provisional regulations as to the navigation of vessels in the river. Also, the IO's regulations were not valid merely because the Porte was one of the powers represented in the Commission, and the river traversed Ottoman territories. ${ }^{39}$

Stokes was in a difficult position, caught between this juridical decision and his government's clear political support for the Commission. Britain's commitment to the organisation was vital, given the large number of British ships that navigated on the Maritime Danube, and Stokes insisted that British seafarers were instructed to comply with the Commission's regulations. However, although the sentence rejected the IO's legislative attributions, they were confirmed by subsequent international agreements, mainly by the ${ }_{186}$ Public Act, amended by the 1866 Paris Conference (see below). By a new royal order dated 9 April 1866, all rules, orders and regulations contained in the Public Act and its appendices were 'binding and in force' and had 'the force of law upon and against all British subjects' and other British protégées in the Danube Delta area. ${ }^{40}$ By the mid-186os the Commission's decisions were 'binding and in force', not only for subjects of the seven member states that had delegates in the organisation, but for all those who came to value the increased security of Danubian shipping.

\section{Migration and Human Insecurity in a Russian-Ottoman Borderland}

The territorial changes brought by the Crimean War (mentioned in Chapter 2) greatly influenced human mobility and insecurity at the Lower Danube. This was duly noticed by European commissioners. They reported such movements of population to their governments as they could disrupt the Commission's works and thus obstruct a decision of Europe's Concert of Powers. At the same time, the Ottoman government attempted to strengthen its hold of the region that it had gained in $1856-1857$.

Stokes wrote to London that in 1860 Tartars started to migrate from the Crimea into Dobrudja and Bulgaria. In 1861 this mobility was accompanied

by an emigration from Turkey of the people living in the districts in which the Tartars have been located, thus great numbers of Bulgarians have gone over to the Crimea to take the place of the Tartars - and the Russian and German colonies in the Dobrudscha are for the most part

39 Ibid., 95-97.

40 Hertslet's Commercial Treaties, vol. 12, 920-924. 
leaving their comfortable homesteads, the former to return into South Russia, the latter to settle in the Moldavian Bessarabia, where a want of population has been created by the flight of the Bulgarian colonies. These colonies settled in Bessarabia in the early part of the present century, but having been oppressed by the Moldavian Government, now seek to escape its rule.

As some of the Russian and German workers employed by the Commission to quarry stone and hew timber in the Danube Delta area were among those who left, the organisation had 'to import Montenegrins and Transylvanians for the quarries'.11 The resettled Bulgarians were not happy with living conditions in the Crimea, so many of them tried to return to their original villages. In June 1862, 7,000 Bulgarians were brought to Sulina by the Ottoman authorities and shipped inland in barely humane conditions. ${ }^{42}$ The Tartar emigration came with similar human insecurity in the Ottoman province of the Lower Danube, as allegedly the

Turkish Government never made the slightest preparation for the thousands that were known to be coming, and when the first instalment arrived at Kustendjie, no food had been prepared, no shelter provided, and not even a bullock cart in readiness to move the poor creatures from the sea-beach where they were landed. ${ }^{43}$

The Ottoman government did make some preparations to colonise Muslims in the Lower Danube province, whose governor served as a Danube commissioner. Muslim settlements were viewed as a human bulwark against the Russian threat. If preparations were deemed as insufficient, this might have had to do with the scale of migration and the Porte's financial means. As early as 1857 , with the view to preventing foreigners from settling and buying estates in the region (especially in urban localities such as Sulina), properties were 'nationalised' and included into the Sultan's private estates. Pieces of land could be rented to those interested, but the idea was to strengthen the Ottoman Empire's security with a 'cordon of Muslim inhabitants, like Russia did with

41 The National Archives of the United Kingdom (TNA), Public Record Office, FO 78/3217, unnumbered (hereafter unn.) (John Stokes to Earl Russell, Galați, 19 November 1861).

42 Ibid., FO 78/3218, unn. (the same, London, 8 July 1862).

43 Henry C. Barkley, Between the Danube and the Black Sea; or, Five Years in Bulgaria (London 1876), 227 . 
its Cossacks'.44 The colonisation programme started in $1857,{ }^{45}$ and a year later 500-60o households from Lazistan (in the current day Turkish provinces of Rize and Artvin) were encouraged to migrate to the district of Tulcea, where they were granted free land and other privileges. ${ }^{46}$

More incentives and careful negotiation skills were needed to make colonisers stay. Nogai settlers came to Dobrudja in the post-Crimean War years, but they soon requested a return to their homelands, feeling that they were discriminated against by the Ottoman authorities. The Porte was paying salaries and gave rewards to leaders of the Tartar communities, while Nogai chieftains complained about the precarious condition of their brethren. As 'Tatars and Nogais are in rivalry', the Ottoman authorities decided to repair the 'injustice', and the political and religious leaders of the Nogai settlers were also properly remunerated and honoured.$^{47}$ At the same time, the Porte was trying to prevent the settlement of colonists whose allegiance was more questionable. This was the case with several Cossack families and their priests from Anapa, who were allegedly steered towards Dobrudja by pro-Russian agents. ${ }^{48}$

As all these movements of population happened in or close to their area of jurisdiction, commissioners kept reporting on these demographic factors that risked increasing regional instability and disrupting their works. Soon they had to shift their observer status by actively trying to solve some of the issues. In this context, the story of the Lipovan fishermen of Vylkove is relevant both for the transformation of the Danube Delta into a hub of human insecurity and for the Commission's metamorphosis into an agent of regional order and stability.

\section{The Fishermen of Vylkove, Border Disputes and the Commission as a Conflict Mediator}

Esngelhardt had a special interest in the ethnic and religious diversity of the Danube Delta, which he described in his official reports and in one of his volumes. ${ }^{49}$ Lipovans or Old Believers were among the most interesting inhabitants of the region. They had migrated westwards from the Ukrainian

Türkiye Cumhuriyeti Cumhurbaşkanlığı Devlet Arşivleri Başkanlığı (Republic of Turkey Presidential State Archives, formerly known as Başbakanlık Osmanlı Arşivi - hereafter BOA), HR.SYS 1604/55 (5 February 1857).

49 Éd. Engelhardt, Études sur les embouchures du Danube (Galați 1862), 35-50.
} 
provinces during the eighteenth century, fleeing religious persecution by the Russian authorities. Some families had settled in the Danube Delta, on the fluid and winding border between medieval Moldavia and its suzerain power, the Ottoman Empire. The Lipovans lived on fishing and a large community was that of Vylkove (Vâlcov), the main hub of the Lower Danubian fishing industry. When Russia annexed the eastern half of Moldavia in 1812 and took over the entire Delta in 1829, the Lipovans returned under Russian control. A new border change occurred after the Crimean War, which further aggravated the already difficult conditions of this fishing community. Situated on the left bank of the Danube, Vylkove became part of Moldavia in 1856, but the village was doubly disconnected from its fishing grounds (taken over by the Ottomans), and from its main markets - Bessarabia and the Ukrainian provinces of the Russian Empire.

The Moldavian and Ottoman authorities lost no time in imposing their sovereignty on the territories they acquired in 1856 . In both cases territorial control and sovereignty took an economic form, that of farming out different monopolies to private contractors who secured quick revenues for state budgets. In Moldavia, fishing was farmed out to a contractor who imposed a tithe of 10 per cent on the catch and had a monopoly on the fish trade. The Lipovan community of Vylkove strongly opposed these conditions, and their petitions were eventually successful in March 1860 when the tithe was provisionally suspended. ${ }^{50}$ The border between Moldavia and the Ottoman Empire in the Danube Delta was as burdensome. As Vylkovians fished in Ottoman waters, imperial authorities made them pay a high tithe, while customs duties had to be paid to both Moldavia and the Ottoman Empire when the catch was brought to Vylkove (see Fig. 4). All in all, the fishermen paid taxes amounting to 32.9 per cent for the fish caught in Ottoman waters and sold in Moldavia, and 40.4 per cent for the catch further exported and sold in the Russian Empire. Moreover, the Lipovans lost other significant privileges, such as the right to cut firewood and to harvest reeds in the Danube Delta, advantages forbidden or heavily taxed by the Ottomans. ${ }^{51}$

The Vylkovians complained that their situation had become even more miserable than during Russian times, and the community considered migrating towards more hospitable lands. They petitioned the Moldavian and Ottoman authorities and asked for redress, but without much success. However, for the

\footnotetext{
50 Procès-verbal des discussions de la Commissions Européenne du Danube relatives à la délimitation entre la Turquie et la Moldavie sur le bras de Kilia, et aux droits de pêche de la Commune de Wilkov (122 e Protocole de la Commission) (Galați 1861), 3.

$5^{1} \quad$ Ibid., $3^{-4}$.
} 


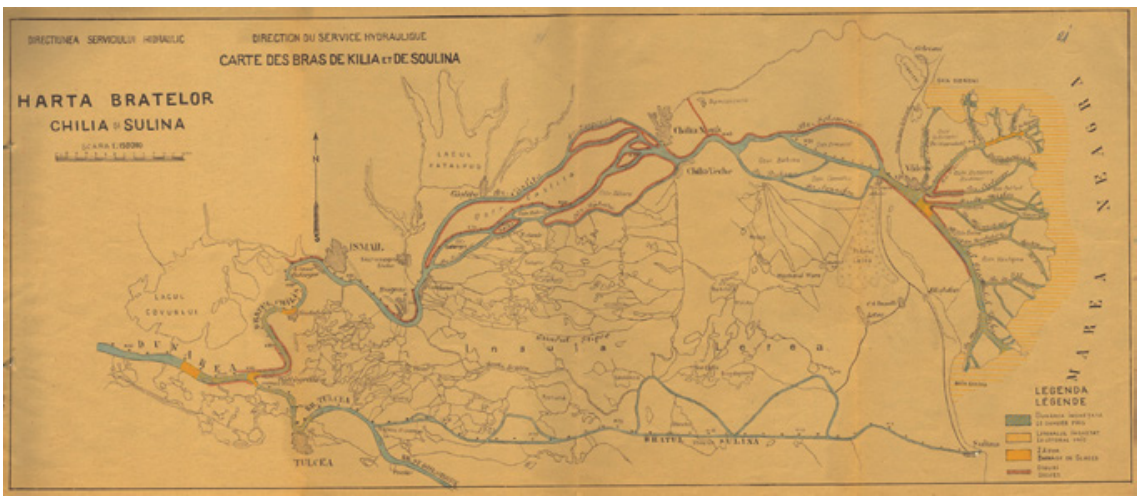

FIGURE 4 Map of the Chilia and Sulina branches of the Danube SOURCE: NATIONAL ARCHIVES OF ROMANIA, GALAȚI BRANCH

Moldavian authorities their cry for help proved useful as an exercise in nationand state-building.

The question of the Ottoman-Moldavian border in the Danube Delta was raised in 1857 in Moldavia's new provisional 'Parliament', the Ad hoc Divan. A petition was drafted and sent to Europe's Great Powers, but it received little attention during the negotiations which resulted in the adoption of the 1858 Paris Convention, the United Principalities' new constitutional charter. ${ }^{52}$ As the Vylkovians' misfortune and protests had grown during those years, the episode was used by the Moldavian authorities to prove the practical downsides of the Ottoman appropriation of the entire Danube Delta. Prince Alexandru Ioan Cuza made this a topic in his relations with the Ottoman Empire, in his attempt to both expose the Porte's abuses and to strengthen his country's individual (i.e. independent) existence.

Cuza relied on Emperor Napoleon In's benevolence to include the question on the Great Powers' agenda. ${ }^{53}$ With French backing, Cuza intended to renegotiate the borderline, which would have served several of his country's political and economic priorities. Given its alleged Romanian and Christian character, the Danube Delta was part of the lost territories claimed by the Romanian motherland, but Cuza was mainly interested in gaining access to a navigable waterway, much needed to boost the economic development of the United

52 French commissioner Engelhardt reported on the border issue, stating that a more independent and national administration would protest against the Porte's confiscation of the entire Danube Delta - CADN, CED/B/10, f. 147-149 (no. 67, 23 July 1858).

53 R.V. Bossy, Agenția diplomatică a României în Paris și legăturile politice franco-române sub Cuza-Vodă (Bucharest 1931), 127-128. 
Principalities. French support was based on a report sent from Galați by commissioner Engelhardt ${ }^{54}$ who was working to advance his country's political interests in Eastern Europe. Cuza raised the question officially and addressed a memorandum to the United Principalities' seven protectors. The Ottoman authorities, Cuza maintained, had disregarded their own practice of having the thalweg (the middle of the chief navigable channel of a waterway) as state border along the entire Lower Danube. This abuse of power by the Ottomans prevented local fishing communities from enjoying their legal rights, which was Cuza's duty to protect. ${ }^{55}$

By late August 1860, Costache Negri, Cuza's diplomatic representative to Istanbul, reported to his prince that their request for an analysis of the border delimitation along the Maritime Danube was accepted by the Great Powers. During a meeting held at the residence of Henry Bulwer, the British Ambassador to Istanbul, European plenipotentiaries agreed to have the problem analysed by the Commission. ${ }^{56}$ From the sources available, it is unclear if this arbitration was decided following Cuza's lobbying through French channels or through the internationalisation of the Vylkovians' cause when Russia started to promote it. The Ottoman Porte accepted an international mediation, in an attempt to avoid being both judge and defendant in the dispute with its vassal state. Through the ambassadorial decision taken in Istanbul, the Commission was entrusted with new powers, eventually turning it into a source of order, security and justice in the Danube Delta.

Discussions on the case (with its two interconnected components - the border delimitation and the Vylkovians' plight) started in November 1860, but they were soon adjourned so as to allow the delegates time to procure the original map used in Paris in 1856-1857, to get more information on the topics and wait for instructions from their governments. ${ }^{57}$ The debates were resumed on 20 May 1861, after the fishermen sent two more petitions and threatened to emigrate if their case was not resolved. ${ }^{58}$

54 Ibid., 187 (No. XIX, 12 February 1860). Engelhardt reported to Paris with details on Cuza's intention to ask for a new delimitation - CADN, CED/B/10, f. 213-214 (no. 98, 8 October 1859).

55 Bossy, Agenția diplomatică, 127.

56 Bossy, L'Autriche et les Principautés-Unies (Bucharest 1938), 162-163 and 276 (no. CI, 21 September 1861).

57 Procès-verbal, sittings of 15 November and 1 December 186o; Engelhardt's opinions in CADN, CED/B/10, f. 259-263 (nos. 123, 124 and 126, 20 November, 2 and 18 December 186o).

$5^{8} \quad$ Procès-verbal, sitting of 3 May 1861. 
Concerning the border issue, two main opinions were formulated in the Commission. The French delegate, Engelhardt, considered that the thalweg of the navigable course was the legal borderline between the United Principalities and the Ottoman Empire. The current border was an error, also caused by the misrepresentation of the Belgorod branch of the Danube, which on the map used in Paris in 1857 appeared as being similar in size to the Sulina branch, though it was in fact thirteen times smaller. ${ }^{59}$ Justice and equity required a resettlement of the border along the thalweg of the navigable course of the Chilia branch, going downstream from the Tchatal (Fork) of Ismail to the mouth of the Stari Stambul sub-branch. The United Principalities were entitled to receive several islands in the northern part of the Chilia Delta, a solution which would also solve the fishermen's claims and secure the United Principalities a navigable connection with the Black Sea. His position was supported by Strambio, the Italian commissioner, whose country followed on the trail of French diplomacy.

The second point of view was that the Porte had been granted direct sovereignty over the entire Danube Delta, including the sub-delta of the Chilia branch, and its right of property covered the whole watercourse. The territory of Moldavia (the United Principalities) started with the terra firma beyond the Delta itself. The delegates from Austria, Great Britain, Prussia, Russia and the Ottoman Empire supported this view. They all sympathised with the poor Lipovan community, which was treated unjustly in the aftermath of the Crimean War. Their interest was, however, not entirely innocent. If Russia's interest in the Lipovan community was linked to the ethnic character of the fishermen, Austria was mainly concerned with their religious identity. The Habsburgs were trying to act as guardians of their religious rights, ${ }^{60}$ and in the border question Becke did not want to contribute to the progress of the Romanian national cause, a threat to all its imperial neighbours.

The position of the Moldavian government was presented by Prince Alexandru Cantacuzino, the prefect of Covurlui County. Cantacuzino sent two memoranda to the Commission, in which he insisted on his country's autonomy and on the fact that the 1857 Protocol hurt Moldavia's historical rights in the Danube Delta. Juridically, the thalweg principle had to be imposed, as the Danube's thalweg separated the Principalities from the Ottoman Empire for several hundred kilometres along the entire course of the river below the Iron

59 Ibid., sitting of 20 May 1861. CADN, CED/B/10, Engelhardt's Memorandum - Note sur l'etat d'innavigabilité du bras secondaire de la Kilia désignée sur le nom de Belgorod, f. 280-284.

6o Arhiereul dr. Veniamin Pocitan Ploeșteanu, Momente din viața și activitatea lui Melchisedec intre anii 1856-1861 (Bucharest 1936), 70-72. 
Gates. ${ }^{61}$ His solution, which would have solved the local inhabitants' claims, was to settle the border along the middle or the Sulina branch of the Danube. ${ }^{62}$

It became clear that geographical knowledge and its interpretation played a major part in this dispute. One of the dissensions was related to the status of the Belgorod sub-branch. From his visits to the area, Engelhardt stated that it was very shallow (i.e. unnavigable), and Strambio denied that it was in fact a separate branch of the Danube. Offenberg opposed these views, as Belgorod discharged its waters into the Black Sea, and seasonally its course was very deep. Stokes mentioned his own visit to the area in the spring of 1861, when he found 12 feet of water at the entrance into the sub-branch, 7-15 feet along its course, and $4^{1 / 2}$ feet at its mouth, conditions which were only a little inferior to those of the Oceakov sub-branch. ${ }^{63}$ It was clearly an impasse. The commissioners had collected a huge amount of information on the local geography and hydrography of the Danube Delta, but they could not agree on things like: What characteristics define the separate 'identity' of a branch of a river in such a labyrinthic area? How deep should a waterway be to be considered navigable? For how many months a year should its physical characteristics be recorded?

A decision was eventually taken by majority vote: the border should be the thalweg of 'the most northern branch of the Danube', which excluded 'all and every one of the Islands of the Delta from Moldavia'. ${ }^{64}$ As for the Vylkovians' petitions, a compromise was reached on 31 July 1861, when the seven commissioners decided to urge Moldavia and the Ottoman Empire to conclude an agreement and protect the Danubian fishermen's rights. The Porte was to grant them full customs and tithe exemption for catches fished within the limits of their communal fishery. A fixed annual sum replaced all other taxes for fish caught in Ottoman waters outside the limits of their concession. They could cut firewood and harvest reed in the islands of the Chilia Delta. The Moldavian government granted them exemption from paying import duties for their fishery products, and full equality of treatment was applied to this commune, in

61 Procès-verbal, Appendix IV, Mémoire du Gouvernement Moldave, présente à l'Honorable Commission Européenne du Danube, par le Prince Alexandre Cantacuzène, 10/22 May 1861.

62 Documente privind domnia lui Alexandru Ioan Cuza, edited by Dan Berindei, Elisabeta Oprescu and Valeriu Stan (Bucharest 1989), 288-29o (no. 382, 29 July 1861).

63 TNA, FO 78/3217, unn. (Stokes to Russell, Galați, 13 April 1861); CADN, CED/B/8, f. 51-52 and $64-65$ (nos. 4 and 5, 9 August and 27 September 1861).

64 TNA, FO 78/3217, unn. (Stokes to Russell, Galați, 1 August 1861); CADN, CED/B/10, f. 276277 (no. 137, 22 July 1861). 
relation to domestic taxes of all kinds, transit and export duties. The monopoly granted for the sale of fish was abolished. ${ }^{65}$

The episode is relevant for the progress of the Commission at a time when it was trying to clarify its prerogatives at the Maritime Danube. While regulating Danubian shipping, the IO claimed for itself several attributions that in fact belonged to the territorial power, the Ottoman Empire. The early 1860 s was a period when the status of the organisation was still unclear, and this arbitration gave it additional prestige as a source of law and order in an interimperial contact zone. The Commission did manage to act as an intermediary between local and national actors and contributed to the production of specialised knowledge and to decision-making in its area of expertise. Maps were extremely important in this, and the settlement showed how they could be used or abused as political tools.

The border question returned to public attention in the mid-1870s, during the Eastern Crisis, when Romania insisted on reaching a convenient solution in its dispute with the Porte. When the treaties of San Stefano and Berlin were signed in 1878 , Russian diplomats took the precaution of clearly mentioning the new configuration of the Russian Empire's southern border (more in Chapter 8). Russia reannexed Southern Bessarabia, Romania received the province of Dobrudja and the Danube Delta, while the borderline along the Maritime Danube was to follow the thalweg of the Chilia branch and the mouth of the Stari Stambul. Even more importantly, the Commission was granted, with Russia's approval, the right to arbitrate the division of waters and fisheries between two sovereign states, Romania and the Russian Empire. ${ }^{66}$

\section{A Transnational 'Constitution' - the ${ }_{1865}$ Public Act}

In 1861, with the success of the provisional works in Sulina, several commissioners considered that the Commission had fulfilled its mission and could be disbanded, according to the provisions of the 1856 Paris Treaty. The proposal came from Engelhardt and Offenberg, who on 21 May 1861 also referred to the need to conclude a Public Act that was to include 'the main results of the activity of the European Commission and the guarantees which Governments consider appropriate in order to safeguard their interests during the interim

\footnotetext{
65 Procès-verbal, sitting of 29June 1861; details on the arrangement in Ștefan Stanciu, România și Comisia Europeană a Dunării. Diplomație. Suveranitate. Cooperare internațională (Galați 2002), 75-77.

66 Les grands traités politiques. Recueil des principaux textes diplomatique depuis 1815 jusqu'à nos jours (Paris 1912), 224.
} 
regime. ${ }^{67}$ Discussions continued a month later, when Austria's Becke supported such an Act, which was to mark the conclusion of the first period in the Commission's activity, but which also signalled that its work was not complete. The document had to make reference to the works done and to their results, and include an abstract of the rights and obligations assumed by all interested parties, the financial state of the organisation and the situation of the international staff that was still needed at the Maritime Danube. ${ }^{68}$ Becke also announced that his government opposed the dissolution of the Commission, as at that moment the Riparian Commission (that was to succeed the European Commission) was not ready to take over the administration of the Danube. ${ }^{69}$

Becke and Engelhardt were appointed to draft the Act, and their colleagues assisted with various other documents. ${ }^{70}$ Discussions started in the autumn of 1861, and negotiations proved extremely complicated due to the strong opposition of the Porte, which considered that several of the Act's articles violated Ottoman sovereignty in the Danube Delta. ${ }^{71}$ Prejudiced by their experience with working with allegedly corrupt Ottoman bureaucrats, the six nonOttoman commissioners wanted to be in charge of naming the officials who were to be entrusted with imposing the Commission's regulations at Sulina and along the Maritime Danube. Legally, it was the Porte's right to appoint such officials in Ottoman territory, but as the Danube Delta was a 'gift' from Europe to the Ottoman Empire, 'it would hardly be a great sacrifice on her [the Porte's] part to concede to Europe an entirely international administration of the navigation: ${ }^{72}$

The Sublime Porte naturally feared that the Act would allow the Commission to 'interfere with her authority on the Danube'. As the project of the Public Act was accepted with minor changes by all interested governments, the six commissioners wrote to their ambassadors in Istanbul to press the Porte into accepting the document. The commissioners considered that their precaution was 'directed solely towards the protection of the public revenue of the navigation from spoliation, and towards the maintenance of that strict order in the river, without which there can be no security for property. ${ }^{\prime 3}$ It was equally

\footnotetext{
$67 \quad$ PECD, Protocol 129, 21 May 1861.

68 Ibid., 20 June 1861.

69 Spiridon G. Focas, The Lower Danube River: In the Southeastern European Political and Economic Complex from Antiquity to the Conference of Belgrade of 1948 (Boulder and New York 1987), 294.

$70 \quad$ PECD, Protocol 129, 22 June 1861.

71 Early opinions of Ottoman commissioner Ömer Fevzi Pasha at BOA, I.HR 186/10349 (21 M 1278) (29 July 1861).

72 TNA, FO 78/3218, unn. (Stokes to Russell, Galați, 25 January 1862).

73 Ibid., unn. (the same, London, 21 August 1862).
} 
important in order to regulate the relations between the Commission and local and consular authorities in the Danube Delta during a period when, as presented above, the Commission's powers and the compulsory character of its regulations were still being questioned. ${ }^{74}$

The Ottoman counterproposals were discussed on 17 October 1862 and they altered the character of the Public Act. The Ottoman Empire claimed full sovereignty in the Danube Delta in its capacity as territorial power. The other six commissioners tried to accommodate the Porte's alterations with their own interests, and the example of the Central Commission for the Navigation of the Rhine was given to prove that international cooperation was possible in similar organisations. ${ }^{75}$ Further discussions took place in Galați in $1863,{ }^{76}$ but the most important negotiations followed in Istanbul between Ottoman ministers and the Great Powers' ambassadors. Eventually, an agreement was reached, and the document was signed by the seven commissioners on 2 November $1865 .{ }^{77}$

The Public Act contained three parts. Title I included the provisions relating to the material conditions of navigation. It placed all the Commission's works and establishments under 'the guarantee and protection of international law'. It reserved 'the power to design and cause to be carried out' all other hydraulic and regulatory works necessary for the security of navigation along its jurisdiction. The Porte allowed the Commission to use the left bank of the river at Sulina to host its mechanical workshops, and granted it land for its administrative buildings on the opposite bank. It also agreed to communicate with the Commission and accept its control in relation to any public or private constructions such as landing jetties, quays or other similar establishments, which could in any way 'compromise the effect of the works of improvement' coordinated by the IO. The provisions relating to the administrative control of navigation (Part 2) were as important. Local navigation was governed by the 'Regulation of Navigation and Police', enacted by the Commission. The regulation was binding as law, not only in relation to the river police, but also for the judgments of cases of civil procedure arising from the exercise of the navigation.

The exercise of navigation on the Maritime Danube was placed under the authority and the superintendence of the Inspector General of the Lower Danube, and of the Captain of the Port of Sulina. These two executive agents

74 PECD, Protocol 146, 12 September 1862.

75 Ibid., 17 October 1862; TNA, FO 78/3218, unn. (Stokes to Russell, Galați, 28 October 1862).

76 TNA, FO $78 / 3219$, unn. (the same, 7 November 1863 ).

77 For its significance according to Ottoman and Austrian sources, see İlhan Ekinci, Tuna Komisyonu ve Tuna'da Ticaret (1856-1883), PhD dissertation, University of Samsun (Samsun 1998), 180-188 and Gătejel, 'Imperial Cooperation': 790-793. 
were named by the Sublime Porte, but they were to conform all their acts to European regulations. Sentences emanating from their authority were pronounced in the name of the Sultan. The Act further detailed proceedings in case of delinquency or offence by these agents, with the Commission being allowed to take part in the enquiries, and 'when the culpability of the accused shall have been duly proved, the Sublime Porte will provide without delay for his being replaced'. The agents were to act 'under the superintendence of the Commission and were to be paid by the Ottoman Government', having been chosen from competent persons.

The two agents' authority was exercised towards all flags without distinction. Merchant captains, of whatever nationality, were bound to obey the orders given to them by virtue of the Regulation of Navigation and Police. Enforcement of the Regulation of Navigation and Police, as well as the application of the Commission's tariff, was insured by the action of the vessels of war stationed at the mouths of the Danube. Each naval force acted upon its own vessels, and upon those whose flag it was called upon to protect. In the absence of a vessel of war qualified to interfere, the executive agents could have recourse to the warships of the territorial power.

The tariff of navigation dues was drawn by virtue of the right to impose a toll of a rate suited to cover the expenses of the works and establishments mentioned above. It furnished the Commission with the resources necessary for the completion of the Sulina works, and it was expressly agreed that the tariff was binding for the future. It also stated how the proceeds of the tax were to be used (see Chapter 5 ). At the expiration of every five-year term, and with a view to diminishing, if possible, the burdens imposed upon the navigation, delegates of the seven powers were to revise its provisions, and the amount of the toll was to be reduced as much as possible, always, however, maintaining the mean revenue judged necessary for covering the Commission's expenses.

It detailed how tolls were to be collected and how the Navigation Cash Office of Sulina was administered. The agent charged with the collection of tolls was appointed by the Commission and acted under its immediate orders. The general control of the transactions of the Cash Office was exercised by an Ottoman auditor. A balance sheet of the Commission's financial operations had to be published annually in the official journals of the different powers interested, together with a statement, making known the distribution and appropriation of the proceeds of the tariff. The Commission was to pay its fair share to the General Administration of the Lighthouses of the Ottoman Empire.

The Public Act further regulated the Danubian quarantine. The sanitary measures applicable to the mouths of the Danube were regulated by the Superior Board of Health in Istanbul, in which various foreign missions accredited to 
the Sublime Porte were represented by delegates. These measures were to be framed so as to conciliate to a just degree security for the public health with the requirements of free maritime trade.

According to Part 3, the works and establishments of all kinds created by the Commission, particularly the Navigation Cash Office at Sulina, enjoyed the neutrality stipulated by Article 11 of the Paris Treaty 'and shall be, in case of war, equally respected by all the belligerents'. The benefits of neutrality were extended to the General Inspectorate of Navigation, to the administration of the port of Sulina, to the staff of the Navigation Cash Office and the Seamen's Hospital, and, lastly, to the technical staff charged with the superintendence of the Commission's hydraulic works. ${ }^{78}$

The Public Act was accompanied by two updated versions of the Commission's most important regulations: 'The Regulation of Navigation and Police Relative to the Lower Danube' and the 'Tariff of Navigation Dues to be Levied at the Mouth of the Danube', as well as by an arrangement relative to the repayment of the advances made by the Sublime Porte for the improvement of the navigation of the mouths of the Danube in 1856-1860. ${ }^{79}$

The Public Act was examined and sanctioned in March 1866 in the framework of an ambassadorial conference summoned to Paris to discuss Romania's situation after Prince Cuza's forced abdication following a coup d'état in Bucharest. The Public Act was sanctioned without much discussion, and the Commission's term was extended by five more years, to allow its engineer-inchief to complete the permanent works from Sulina. The request to extend the IO's jurisdiction from Isaccea to Brăila, which would have allowed the Commission to exercise its attributions over the entire Maritime Danube, was, however, rejected: the Ottoman delegate, Safvet Pasha, considered that it infringed upon the sovereign rights of the Ottoman Empire. ${ }^{80}$

The Public Act was presented in the national parliaments of member states. In Britain it was discussed in February 1867 and some of the criticism in the local press is illustrative of how international cooperation was regarded at the time. The 1866 Paris ambassadorial conference acted like the Parliament of England or the Congress of the United States, without reference to the constituencies that created it, or to the Laws which it has to administer', thus in open contempt of Britain's national laws. As for the Public Act, its unusually ambiguous language allegedly favoured Russia, the power defeated in

78 The text in Acte public relatif à la navigation des embouchures du Danube signé à Galatz, le 2 novembre 1865 (Galați [1865]); also in Dimitrie A. Sturdza, Recueil de documents relatifs à la liberté de navigation du Danube (Berlin 1904), 80-89.

$80 \quad$ British and Foreign State Papers, vol. 57 (London 1871), 546-553. 
the Crimean War. Article I charged the Commission or the organisation to succeed it

with all authority which the requirements of the navigation may demand, to the exclusion of 'all interference whatever'. That is to say, that whatever the Commission may do, the Porte must not presume to object. In short, the temporary European Commission, of which Russia is a member, is to be permanent, and the permanent River Commission of Articles XVII and XVIII of the Treaty of Paris, of which Russia was not to be a member, vanishes out of sight.

Further criticism referred to the attributions of the two international executive agents. The conclusion of the article returned to the Russophobic spirit that still affected British public opinion: 'the European Commission of the Danube is a fulfilment of all that was said beforehand by Lord Ponsonby and Mr Urquhart of the perfidy of the Crimean War'. ${ }^{\prime}$

In the end, the irony was that the Public Act, which several commissioners wanted to conclude before disbanding the Commission, contributed to strengthening the institution. It served as its 'Constitution' and clearly defined its legislative, executive and juridical functions in its territorial jurisdiction, where its staff and assets enjoyed a neutral status and numerous privileges. Or to switch perspective, to a Soviet historian, the document 'legitimised the undisguised conduct of foreign imperialists at the mouths of the Danube'. ${ }^{82}$

As the Riverain Commission was still not ready to take over the administration of Danubian navigation, the Commission assumed larger attributions which allowed it to fulfil its, by now, techno-political tasks. Just how large the Commission's powers were is evident in a report authored by France's commissioner Engelhardt; preceding the conclusions, it demonstrates how much the organisation had progressed during the period 1856-1866.

\section{On the Commission's Exceptional Character}

Engelhardt was the youngest of the seven 'founding fathers' of the Commission and its first secretary, entrusted with drafting the organisation's protocols. This mission fitted well with his passion for writing and sense of order. Engelhardt

\footnotetext{
81 'The European Commission at the Mouth of the Danube,' Diplomatic Review 16.3 (4 March 1868): $38-40$.

82 M.V. Pochkaeva, Mezhdunarodno-pravovǒ rezhim sudokhodstva na Dunae (Moscow 1951), 18.
} 
came to Galați for two years and stayed for eleven, and his juridical knowledge contributed enormously to turning a temporary commission into an IO that closely resembled a sovereign state. His long stay in the Danube Delta area and his dealings with the Commission's business turned him into a legal expert with innovative views on the structure and rules that governed the international system. The Frenchman was recognised as an authority in the international law of transboundary rivers (which he discussed in several publications ${ }^{83}$ ), but also in colonial issues, an extension of his experience in the Ottoman lands, which he greatly used during the $1884-1885$ 'Congo Conference' in Berlin.

In 1866, ten years after the establishment of the Commission, Engelhardt published several memoranda on the activity and achievements of the organisation, which had managed to transcend the temporal and jurisdictional limits of the $185^{6}$ Paris Treaty. He briefly referred to the circumstances which caused the Commission to turn into a transnational organ that enjoyed an exceptional position in the international system. Endowed with attributions that derived from the principles of sovereignty, extraterritoriality and neutrality, the Commission was virtually an independent state whose mission was to safeguard freedom of navigation on the Maritime Danube, one of the main decisions of Europe's Concert of Powers in $1856 .{ }^{84}$

Commissions established for international rivers, such as the Central Commission for the Navigation of the Rhine, were deliberative bodies of riparian states. They negotiated collective interests and their decisions were compulsory once ratified by all member states, which also enforced their application along the territorial waters of each signatory country. Supervision and control belonged to a permanent organisation which, however, had only limited attributions in relation to sovereign riparian states. The Central Commission for the Navigation of the Rhine and other river commissions kept national sovereignty as one of their guiding values. It encouraged supranational cooperation only as much as it did not infringe upon the sovereign rights of member states, and this synergy was meant firstly for the benefit of riparian countries.

To Engelhardt, the Commission was a different type of river commission, which was meant to regulate on a different dimension. As a deliberative body, it could decide on anything that concerned commercial navigation along its territory of competence, i.e. the course of the Maritime Danube. It drafted regulations governing navigation and river police, it decided the rate of the navigation tolls to be paid by ships of all nations and planned the hydraulic works

83 Engelhardt, Du régime conventionnel des fleuves internationaux, avec une introduction historique (Paris 1879); idem, Histoire du droit fluvial conventionnel (Paris 1889).

84 Engelhardt, Second mémoire sur les travaux de la Commission Européenne du Danube (Galați 1866). 
it deemed necessary. Once voted in the Commission, these decisions became mandatory, and the Commission issued them publicly and on behalf of itself. To carry out its task, the organisation had a secretary general, an engineer-inchief and many other employees, who were not appointed by member states, but whom the Commission itself could freely choose and revoke.

As an executive authority, it applied its own regulations, tariffs and hydraulic plans. To do this, it relied on its own staff, which included an inspector general, four sub-inspectors, a harbour master and a treasurer, all of whom took an oath of allegiance in front of the seven commissioners. The Commission drafted and promulgated laws governing navigation on the Maritime Danube, supervised and enforced their execution, but also judged any offences against these laws. As a court of appeal, it could annul, change or confirm the sentences pronounced, in the name of the Sultan, by its agents, who acted as judges in the first instance. The Commission's decisions were final, and by 1866 several European states had already decided that they were valid within their national boundaries. ${ }^{85}$

In many respects, the Commission had the attributes of an autonomous government. It had concluded an arrangement which regulated its relations with the Ottoman Empire, the formal owner of the Danube Delta, and it established direct 'diplomatic' relations with neighbouring states. By the mid-186os, the Commission had an income of about 900,00o francs a year and drafted a budget of incomes and expenses. To complete massive infrastructure works, it had contracted loans from international banks and even issued bonds; it thus managed to collect more than 4,000,00o francs, which it invested in the hydrotechnical works and regulatory establishments along the Maritime Danube. The Commission enjoyed postal, telegraphic and customs immunities in the Ottoman Empire and Romania, the main beneficiaries of its improvements. It owned, in its name, estates totalling more than fifteen hectares, buildings worth about 500,000 francs, and a fleet of about thirty service ships. These vessels hoisted the Commission's own flag, and their official papers were issued by the Commission, not by the territorial authority. ${ }^{86}$

All these large prerogatives seemed contrary to common law, and the Commission had already been described as 'a state within a state'. But in having reserved so many attributions for this IO, Engelhardt and his associates had taken into consideration the exceptional circumstances within which the Commission had to fulfil its task. The independence to which the commissioners aspired to from the very beginning was 'legitimate and necessary', given the disorder, anarchy and arbitrariness that ruled in the Danube Delta

$\begin{array}{ll}85 & \text { Ibid., } 28-29 . \\ 86 & \text { Ibid., 30. }\end{array}$ 
before and after the Crimean War. The Porte, which had received this territory in 1856-1857 through the resolution of the western victors, could not provide the 'guarantees of order and security which European navigation imperiously needed', and so the Commission assumed such supranational attributions as needed to enforce the stipulations of the 1856 Paris Treaty. ${ }^{87}$

Engelhardt was happy with this organisation, a Commission wisely ruled by a European septumvirate, which attempted to bring 'order and security' through proper knowledge and modern statehood techniques ${ }^{88}$ in a far-off Ottoman periphery. Their republic was a juridical innovation designed to enact the generous and liberal principles of 1856 , and it had succeeded thanks to the diplomatic, administrative and technical skills of a few visionaries who managed to convince their governments, the Sublime Porte and local economic circles that the Commission could institute and preserve free navigation along the Maritime Danube.

\section{Conclusions}

By 1866 the Commission was a functional organisation that had gradually evolved beyond the temporary and jurisdictional scope envisioned by the artisans of the 1856 Peace Treaty. Although the seven delegates acted according to the instructions received from their governments, the Commission came to stand for something more than the narrow interests of each member state. The organisation took decisions that were observed by the shipmasters of various other countries. In 1864, just before Engelhardt published his memoranda, the Maritime Danube was visited by vessels under twenty-one national flags (Austria, Belgium, Bremen, Denmark, France, Great Britain, Greece, Hanover, the Ionian Islands, Italy, Mecklenburg, the Netherlands, Norway, Oldenburg, the Ottoman Empire, Prussia, Romania, Russia, Serbia, Sweden and the United States). ${ }^{89}$ The Commission was an efficient technocratic and bureaucratic structure that planned and executed complex hydraulic works along the Sulina branch of the Danube. It also devised rules and was applying them effectively and impartially, turning the river into a secure waterway.

Engelhardt's account was certainly subjective and self-eulogising. The Commission was an embodiment of western influence in the Ottoman Empire, and the Porte had to accept supranational control over a portion of its sovereign

\footnotetext{
87 Ibid., $31-32$.

88 Charles S. Maier, 'Leviathan 2.o: Inventing Modern Statehood,' in: Emily R. Rosenberg (ed.), A World Connecting. 1870-1945 (Cambridge MA and London 2012), 29-282.

$89 \quad$ PECD, Statistique de la navigation (Galați 1864).
} 
territory. This form of shared multi-imperial control over a strategic European waterway started as a provisional solution while transferring to the Ottoman Empire a strip of land disputed by Russia and Austria. This was, in some ways, similar to the status of the Principalities, which in 1856 were maintained under Ottoman suzerainty, but were at the same time placed under the collective guarantee of Europe's Concert. Soon enough, non-riparian powers witnessed the renewed hydro-hegemonic tendencies of Austria and the 'anarchy' in the Danube Delta, as the government in Istanbul could hardly control the region better than the Russians had done before 1854 or the Austrians in 1855-1857. Their 'informal collective imperialism' resulted in the Commission gradually assuming larger attributions, to which all seven signatory powers of the 1856 Paris Treaty were associated. The Commission was a functional instrument of 'collective imperialism, ${ }^{90}$ and it gradually turned from an international technical advisory board into an executive organ that was to govern navigation along the Maritime Danube.

'Governance' and 'governmentality'91 are appropriate concepts to cover the Commission's work in bringing law and order to the Danube Delta. In an area where the Ottoman state was gradually imposing its sovereignty, agents of Europe's Concert of Powers came with their modern ideas about efficient and reliable administration. In attempting to put an end to arbitrary policymaking, unaccountable officials or impracticable legal provisions, commissioners started to impose 'good governance', based on the rule of 'European' law. International governance stemmed from the commissioners' complete mistrust in the Ottomans' ability to administer international navigation along the Danube, which, according to the 1856 Paris Treaty, had become 'a part of the Public Law of Europe' and was under the Great Powers' guarantee (Chapter 2). Ottoman sovereignty was supplemented with European governmentality, as corpuses of knowledge and governing techniques were implanted in the Danube Delta. They were shaped through the decision-making mechanisms presented above and were directed towards 'disciplining' both the local entrepreneurial community and the Ottoman officials, all regarded through orientalising spectacles. The mixture between modern administrative practices and the establishment of European policies and institutions was already functional in the first decade of the Commission's existence, turning the Danube Delta into a laboratory of collective imperial governance, based on a hybrid of transnational governmentality.

\footnotetext{
9o Iordachi, 'Collective Imperialism' cit.

91 Ruud Janssens, 'Governance' and Renault Payre, 'Governing Science,' in Akira Iriye and Pierre-Yves Saunier (eds.), The Palgrave Dictionary of Transnational History. From the Mid19th Century to the Present Day (Basingstoke 2009), 465-466 and 466-470.
} 